\title{
Monitoring of risk metals in chub (Leuciscus cephalus L.) from the Svitava and Svratka rivers in the urban area of Brno, Czech Republic
}

\author{
Veronika Harkabusová ${ }^{1}$, Olga Čelechovská ${ }^{1}$, Alena Lavičková1, Zdeňka Svobodová \\ ${ }^{1}$ Department of Biochemistry, Chemistry and Biophysics, ${ }^{2}$ Department of Veterinary Public Health \\ and Toxicology, Faculty of Veterinary Hygiene and Ecology, University of Veterinary \\ and Pharmaceutical Sciences, Brno, Czech Republic
}

Received December 11, 2011

Accepted February 14, 2012

\begin{abstract}
The aim of this study was to assess the impact of the Brno agglomeration on the distribution of risk elements ( $\mathrm{Pb}, \mathrm{Cd}, \mathrm{Cu}, \mathrm{Zn}, \mathrm{As})$ in tissues of a total of 50 chub (Leuciscus cephalus L.). Contamination by metals was monitored in fish from different sites on the Svitava and Svratka rivers in the urban agglomeration of Brno in 2008. Metal concentration was determined in the muscle, liver and kidney by high-resolution atomic absorption spectrometry. Electrothermic technique was used to assess lead, cadmium and copper concentrations; zinc content was determined by flame technique and arsenic by hydride generation. The highest concentrations of cadmium, lead, arsenic and zinc in individual tissues, ranked in a descending order as follows: kidney $>$ liver $>$ muscle; for copper it was liver $>$ kidney $>$ muscle. The highest concentrations of cadmium, arsenic and zinc were determined in chub kidney from the locality of Kníničky $\left(1.35 \pm 0.97,0.186 \pm 0.076\right.$, and $299.7 \pm 123.4 \mathrm{mg} \cdot \mathrm{kg}^{-1}$ respectively); the highest concentration of lead was on the Svratka before junction $\left(0.28 \pm 0.19 \mathrm{mg} \cdot \mathrm{kg}^{-1}\right)$. The highest contamination with risk metals was found in chub from the Svratka. The assessed concentrations have shown minimum participation of the Brno agglomeration in the accumulation of metals. The concentrations of all risk elements in chub from all of the monitored localities do not pose any environmental or health threat. This study updates published data on chub from the Rivers Svitava and Svratka on concentration of risk elements.
\end{abstract}

Indicator fish, cadmium, lead, arsenic, zinc, copper

Heavy metals such as mercury, cadmium, lead and arsenic constitute a significant potential threat to human health (Castro-González and Méndez-Armenta 2008). Because of low levels of their degradation, the metals accumulate in soil and water sediments and subsequently enter the food chain (Cornelis et al. 2005).

The impact of urban agglomerations on concentrations of risk metals in fish is the subject of many studies, e.g. in the Seine River in France (Chevreuil et al. 1995), in the Savannah in the USA (Burger et al. 2002), and in the Neretva in Croatia (Has-Schön et al. 2006).

The aim of this study was to assess the impact of the Brno urban agglomeration on the concentration and distribution of risk metals in tissues of chub (Leuciscus cephalus L.) as an indicator species caught in the Svratka and Svitava rivers. The work completes existing findings from the mentioned locality regarding the concentration and distribution of other toxic substances in chub (Kružíková et al. 2008, 2009, 2011; Kovářová et al. 2009a; Blahová et al. 2009, 2010).

\section{Materials and Methods}

Study of concentrations of risk elements and their distributions in chub tissues was conducted on the Svratka and Svitava rivers in the urban agglomeration of Brno.

Before reaching the agglomeration, the Svratka flows through an industrial zone (Veverská Bitýška and Tišnov), and its water forms a vast water surface of the Kníničky reservoir in the northwest part of Brno. Then the river flows through the western part of town without any other industrial burden. The Svitava

Address for correspondence:

Ing. Veronika Harkabusová

Department of Biochemistry, Chemistry and Biophysics

Faculty of Veterinary Hygiene and Ecology, University of Veterinary

and Pharmaceutical Sciences

E-mail: h.verunka@centrum.cz

Palackého 1/3, 61242 Brno, Czech Republic

http://www.vfu.cz/acta-vet/actavet.htm 
Table 1. Localities around Brno

\begin{tabular}{|c|c|c|c|c|}
\hline River & Sampling site & River km & Latitude & Longitude \\
\hline \multirow[t]{2}{*}{ Svitava } & Bílovice nad Svitavou & 18.0 & $49^{\circ} 15^{\prime} 6.076^{\prime \prime} \mathrm{N}$ & $16^{\circ} 40^{\prime} 13.641$ ' $\mathrm{E}$ \\
\hline & before junction & 0.6 & $49^{\circ} 8^{\prime} 52.372^{\prime \prime} \mathrm{N}$ & $16^{\circ} 37^{\prime} 51.818^{\prime \prime} \mathrm{E}$ \\
\hline \multirow[t]{4}{*}{ Svratka } & Kníničky & 56.2 & $49^{\circ} 13^{\prime} 14.847^{\prime \prime} \mathrm{N}$ & $16^{\circ} 32^{\prime} 9.821$ '”E \\
\hline & before junction & 40.9 & $49^{\circ} 8^{\prime} 40.073^{\prime \prime} \mathrm{N}$ & $16^{\circ} 37^{\prime} 42.134^{\prime \prime} \mathrm{E}$ \\
\hline & Rajhradice & 35.0 & $49^{\circ} 5^{\prime} 36.502^{\prime \prime} \mathrm{N}$ & $16^{\circ} 37^{\prime} 10.68^{\prime \prime} \mathrm{E}$ \\
\hline & Židlochovice & 30.0 & $49^{\circ} 2{ }^{\prime} 33.312^{\prime \prime} \mathrm{N}$ & $16^{\circ} 36^{\prime} 48.766^{\prime \prime} \mathrm{E}$ \\
\hline
\end{tabular}

Table 2. Characteristics of chub (Leuciscus cephalus L.)

\begin{tabular}{llccc}
\hline River & \multicolumn{1}{c}{ Sampling site } & Fish $(\mathrm{n})$ & Weight $(\mathrm{g})$ mean (median) & Total length $(\mathrm{mm})$ mean (median) \\
\hline Svitava & Bílovice nad Svitavou & 9 & $293(280)$ & $258(255)$ \\
& before junction & 9 & $328(211)$ & $252(250)$ \\
Svratka & Kníničky & 10 & $162(141)$ & $210(200)$ \\
& before junction & 11 & $176(156)$ & $216(210)$ \\
& Rajhradice & 11 & $141(114)$ & $200(190)$ \\
\hline
\end{tabular}

springs in the woody and hilly country around the town of Svitava and flows through a narrow heavily settled valley with advanced mechanical engineering (Blansko and Adamov). Then the river flows through the east part of Brno (a former industrial zone) and after leaving the town joins the Svratka. Table 1 shows the sites on the Svitava and Svratka rivers where chub were captured by electrofishing. Table 2 shows the number of fish caught in each locality, their mean weight, mean total length, and the median of analysed chub samples.

Samples of individual fish tissues were collected immediately after the fish were killed and kept at $-18^{\circ} \mathrm{C}$ until they were analysed. Concentrations of individual metals (lead $(\mathrm{Pb})$, cadmium $(\mathrm{Cd})$, copper $(\mathrm{Cu})$, zinc $(\mathrm{Zn})$ and arsenic (As)) were determined in muscle, liver and kidney samples. Prior to the determination of metal content, the samples were mineralized with nitric acid and hydrogen peroxide in laboratory autoclaves equipped with microwave heating (ETHOS SEL, Milestone Italy). Then, for the determination of arsenic, the samples were burnt to ashes with added $\mathrm{Mg}\left(\mathrm{NO}_{3}\right)_{2}$ in muffle furnace. The ashes were dissolved in $\mathrm{HCl}$ and $\mathrm{As}^{5+}$ was reduced to $\mathrm{As}^{3+}$ with the aid of KI (Čelechovská et al. 2005, 2011).

The concentrations of metals were determined by high-resolution continuum source atomic absorption spectrometry (HR-CS-AAS), using a spectrometer ContrAA 700 (Analytik Jena, Germany). The detection limits $(3 \sigma)$ of $\mathrm{As}, \mathrm{Cd}, \mathrm{Pb}, \mathrm{Cu}$ and $\mathrm{Zn}$ were $2.49,3.04,36.6,80.3 \mu \mathrm{g} \cdot \mathrm{kg}^{-1}$ and $1.35 \mathrm{mg} \cdot \mathrm{kg}^{-1}$, respectively. Standard deviations of parallel determinations were less than 5\%. Samples of certified standard material DORM-2 (dogfish muscle-NRC), BCR 186 (pig kidney) and 1577a (bovine liver-NIST) were used to check the validity and accuracy of the method.

The acquired data were processed by statistical software Unistat 5.1. To assess the agreement $(P<0.05)$ or differences between individual tissue groups, nonparametric median multiple comparisons by Tukey-HSD tests were used.

\section{Results}

Mean concentrations of metals, including standard deviations in individual fish tissues from each individual locality are shown in Table 3. Lower concentrations of metals were found in tissues of chub from the Svitava, which is in agreement with lower concentrations of metals in sediments (Kovářová et al. 2009b). The highest concentrations of cadmium, lead, arsenic and zinc were in kidney. The highest concentrations of copper were analyzed in the liver. The results have shown that metals differ in their affinity to different fish tissues and were in agreement with the study of Has-Schön et al. (2006), Čelechovská et al. (2007) and Yilmaz et al. (2007).

\section{Discussion}

\section{Cadmium}

Cadmium content in individual tissues ranked in a descending order as follows: kidney $>$ liver > muscle. When compared with muscle samples, the concentrations in kidney and 
Table 3. Assessed concentrations (mean and standard deviations) of metals in tissues of chub (Leuciscus cephalus L.)

\begin{tabular}{|c|c|c|c|c|}
\hline \multirow{2}{*}{ Metal } & \multirow{2}{*}{ Locality } & \multicolumn{3}{|c|}{ Tissue concentration of metals (mg/kg) } \\
\hline & & Muscle & Liver & Kidney \\
\hline \multirow[t]{5}{*}{$\overline{\mathrm{Cd}}$} & Bílovice nad Svitavou & $0.009 \pm 0.004^{b}$ & $0.068 \pm 0.038^{\mathrm{c}}$ & $1.350 \pm 0.977^{\mathrm{c}}$ \\
\hline & Svitava - before junction & $0.009 \pm 0.001^{\mathrm{b}}$ & $0.031 \pm 0.017^{\mathrm{a}}$ & $0.440 \pm 0.209^{a}$ \\
\hline & Svratka - Kníničky & $0.010 \pm 0.002^{\mathrm{c}}$ & $0.069 \pm 0.064^{\mathrm{bc}}$ & $0.711 \pm 0.626^{\mathrm{ab}}$ \\
\hline & Svratka - before junction & $0.006 \pm 0.002^{\mathrm{a}}$ & $0.041 \pm 0.016^{\mathrm{bc}}$ & $0.419 \pm 0.209^{\mathrm{c}}$ \\
\hline & Svratka - Rajhradice & $0.008 \pm 0.002^{b}$ & $0.037 \pm 0.018^{a b}$ & $0.473 \pm 0.240^{a b}$ \\
\hline \multirow[t]{5}{*}{$\mathrm{Pb}$} & Bílovice nad Svitavou & $0.077 \pm 0.056^{\mathrm{ab}}$ & $0.093 \pm 0.042^{\mathrm{a}}$ & $0.116 \pm 0.068^{\mathrm{a}}$ \\
\hline & Svitava - before junction & $0.073 \pm 0.056 \mathrm{a}$ & $0.076 \pm 0.052 \mathrm{a}$ & $0.277 \pm 0.187^{b}$ \\
\hline & Svratka - Kníničky & $0.115 \pm 0.048^{c}$ & $0.190 \pm 0.223^{\mathrm{a}}$ & $0.199 \pm 0.181^{\text {a }}$ \\
\hline & Svratka - before junction & $0.089 \pm 0.068^{\mathrm{ab}}$ & $0.118 \pm 0.100^{a}$ & $0.253 \pm 0.184^{\mathrm{ab}}$ \\
\hline & Svratka - Rajhradice & $0.106 \pm 0.057^{\mathrm{bc}}$ & $0.143 \pm 0.090^{\text {a }}$ & $0.189 \pm 0.106^{\mathrm{ab}}$ \\
\hline \multirow[t]{5}{*}{ As } & Bílovice nad Svitavou & $0.030 \pm 0.006^{\mathrm{a}}$ & $0.06 \pm 0.017^{\mathrm{b}}$ & $0.058 \pm 0.017^{\mathrm{a}}$ \\
\hline & Svitava - before junction & $0.040 \pm 0.010^{b}$ & $0.04 \pm 0.013^{\mathrm{a}}$ & $0.058 \pm 0.015^{\mathrm{a}}$ \\
\hline & Svratka - Kníničky & $0.058 \pm 0.012^{\mathrm{d}}$ & $0.164 \pm 0.012^{\mathrm{c}}$ & $0.186 \pm 0.076^{\mathrm{c}}$ \\
\hline & Svratka - before junction & $0.055 \pm 0.038^{\mathrm{c}}$ & $0.04 \pm 0.016^{\mathrm{a}}$ & $0.094 \pm 0.04^{\mathrm{b}}$ \\
\hline & Svratka - Rajhradice & $0.051 \pm 0.014^{\mathrm{cd}}$ & $0.069 \pm 0.018^{b}$ & $0.092 \pm 0.044^{\mathrm{ab}}$ \\
\hline \multirow[t]{5}{*}{$\mathrm{Zn}$} & Bílovice nad Svitavou & $4.340 \pm 1.271^{\mathrm{bc}}$ & $21.41 \pm 5.12^{\mathrm{a}}$ & $125.5 \pm 32.4^{\mathrm{a}}$ \\
\hline & Svitava - before junction & $4.034 \pm 1.430^{\mathrm{ab}}$ & $27.31 \pm 7.81^{\mathrm{b}}$ & $216.9 \pm 59.2 \mathrm{bc}$ \\
\hline & Svratka - Kníničky & $4.916 \pm 1.447^{\mathrm{c}}$ & $29.78 \pm 6.93^{b}$ & $299.7 \pm 123.4^{\mathrm{c}}$ \\
\hline & Svratka - before junction & $3.918 \pm 1.153^{\mathrm{ab}}$ & $29.01 \pm 8.20^{\mathrm{b}}$ & $263.2 \pm 54.7^{\mathrm{c}}$ \\
\hline & Svratka - Rajhradice & $4.912 \pm 1.264^{\mathrm{c}}$ & $27.11 \pm 6.96^{b}$ & $225.4 \pm 61.5^{\mathrm{c}}$ \\
\hline \multirow[t]{5}{*}{$\mathrm{Cu}$} & Bílovice nad Svitavou & $0.097 \pm 0.089^{\mathrm{a}}$ & $11.06 \pm 10.89^{\mathrm{a}}$ & $1.35 \pm 0.13^{\mathrm{a}}$ \\
\hline & Svitava - before junction & $0.207 \pm 0.098^{\mathrm{c}}$ & $16.00 \pm 9.67 \mathrm{abc}$ & $1.57 \pm 0.21^{\mathrm{b}}$ \\
\hline & Svratka - Kníničky & $0.253 \pm 0.093^{\mathrm{c}}$ & $21.98 \pm 8.79^{\mathrm{c}}$ & $1.27 \pm 0.30^{\mathrm{a}}$ \\
\hline & Svratka - before junction & $0.141 \pm 0.086^{\mathrm{b}}$ & $20.31 \pm 10.17^{\mathrm{bc}}$ & $1.36 \pm 0.20^{\mathrm{a}}$ \\
\hline & Svratka - Rajhradice & $0.203 \pm 0.083^{\mathrm{c}}$ & $9.99 \pm 5.74^{\mathrm{a}}$ & $1.43 \pm 0.21 \mathrm{ab}$ \\
\hline
\end{tabular}

Significance of differences between localities at the level of $P<0.05$ is indexed by different superscipts

liver samples were $100 \times$ and $10 \times$ higher, respectively. Kidneys are considered the primary part of body for cadmium accumulation (Has-Schön et al. 2006).

Significantly the highest cadmium content $(P<0.05)$ in chub from the Svitava was assessed upstream of Brno in the locality of Bílovice nad Svitavou. In the Svratka the highest concentrations were found in all tissues of chub from the Kníničky locality, upstream of Brno. Concentrations of cadmium in chub muscle from the Svitava did not vary and concentrations in the liver and in kidneys were decreasing simultaneously with the river flowing through the town. That might be the proof that fish did not ingest any more cadmium. Very similar findings have been published by Kovářová et al. (2009b).

\section{Lead}

Lead distribution between individual tissues, ranked in a descending order as follows: kidney $>$ liver $>$ muscle, which is in accordance with Linde et al. (1999), Has-Schön et al. (2006) and Čelechovská et al. (2007). The highest lead content in muscle $(P<0.05)$ was assessed in the Kníničky locality. Concentrations of lead in kidneys were significantly higher $(P<0.05)$ in fish caught upstream of Brno. Concentrations of lead in the liver did not show any significant differences.

\section{Arsenic}

Arsenic distribution between individual tissues ranked in a descending order kidney $>$ liver > muscle, which is similar to the study of Burger et al. (2002) and Čelechovská 
et al. (2005). At a prolonged exposure of rainbow trout to small doses of arsenic in feeds, its accumulation in muscle was higher than in the liver and kidneys (Čelechovská et al. 2011). We found a negative correlation between the arsenic content in muscle and the chub weight, and between the arsenic content in muscle and the chub total length $(r=-0.83 ; r=$ -0.87 , respectively). On the other hand, Burger et al. (2002) found a positive correlation between the body weight and the arsenic content in various fish from the Savannah river.

The highest concentrations $(P<0.05)$ in all the tissues of chub were found in fish from the Kníničky locality. As for chub muscle, concentrations from the Svitava were lower $(P<0.01)$ in fish caught upstream of Brno. On the Svratka the highest concentrations were found in chub muscle before the river entered Brno and significantly lower $(P<0.01)$ after leaving Brno. This trend on the Svratka was found also for liver and kidney samples, where the difference was highly significant $(P<0.01)$.

Arsenic often accompanies phosphorus due to their similar chemistry, and so higher arsenic concentrations may be caused by the release of phosphates into environment. Formerly, phosphates were a common component of detergents and fertilisers.

\section{Copper and zinc}

Copper and zinc are essential elements carefully regulated by physiological mechanisms in the organism (Bowen 1979). At higher concentrations, copper ions are toxic to fish and some microorganisms. Copper compounds are widely used in industry and are component parts of various preparations used in agriculture and households.

Concentrations of copper in individual tissues ranked in a descending order liver $>$ kidney $>$ muscle; concentrations of zinc ranked in the order kidney $>$ liver $>$ muscle. Many authors have reported uneven organ distribution of zinc in chub (Andres et al. 2000). Concentrations of zinc assessed in chub were higher than reported in fish by other authors (Yilmaz et al. 2007; Čelechovská et al. 2007) and correlated with concentrations of arsenic assessed in chub kidneys $(\mathrm{r}=0.76)$. Higher zinc content in kidneys is connected with its wide metabolic activity and affinity to SH-groups of proteins, including metallothioneins present in kidneys (Yilmaz et al. 2007).

In the Svitava, higher values of zinc concentration were found after its flowing through the town $(P<0.05)$. In the Svratka, the highest concentrations of zinc were assessed in the Kníničky locality (muscle, liver), where the concentrations of zinc in all tissues were significantly the highest $(P<0.05)$ of all of the sites on the Svratka and also when compared to the Svitava.

Generally, concentrations of metals found in chub from the Svitava and Svratka rivers were lower than reported in other studies of fish from other countries (Chevreuil et al. 1995; Linde et al. 1999; Burger et al. 2002; Andreji et al. 2005, 2006; Has-Schön et al. 2006). They did not exceed hygienic limits for muscle meat of fish (Cd: $0.050 \mathrm{mg} / \mathrm{kg} ; \mathrm{Pb}$ : $0.30 \mathrm{mg} / \mathrm{kg}$ ) set by the Commission Regulation (EC) No 629/2008 of 2 July 2008 amending Regulation (EC) No 1881/2006. The highest load by risk metals was found in tissues of fish from the Kníničky locality on the Svratka at the inflow to Brno. The locality is situated right below the dammed reservoir which is an important holiday resort area. High intensity of emissions from the traffic and accumulation of metals in the water sediment, and their subsequent washing out by erosion may be major sources of high accumulation of metals in this locality. For most part of the year the water from reservoir flows out through the bottom discharge outlets, so particles of sediment from the reservoir bed may be carried into discharged water. The whirled sediment easily gets into an organism through the digestive system and gills. Lower metal contents in tissues of chub from the localities farther away from Brno (Rajhradice) may be influenced by the sewage treatment plant on the Svratka, downstream of Brno (Modřice, river km 38.7, 49 $7^{\prime} 34.913^{\prime \prime} \mathrm{N}, 16^{\circ} 37^{\prime} 42.171^{\prime \prime} \mathrm{E}$ ), by the lower residential density there and also by the reduced industrial production. The assessed 
concentrations of metals have shown minimum contribution of the urban agglomeration of Brno to the accumulation of metals there. After the Svitava and Svratka rivers flow through the town, the concentrations do not vary or they show a slightly declining tendency. The concentrations of all risk elements in chub from all of the monitored localities do not pose any environmental or health threat.

\section{Acknowledgements}

This research was supported by the University of Veterinary and Pharmaceutical Sciences IG202111 and by project of Ministry of Education, Youth and Sports of the Czech Republic MSM 6215712402 and 2 B06093.

\section{References}

Andres S, Ribeyre F, Tourencq JN, Boudou A 2000: Interspecific comparison of cadmium and zinc contamination in the organs of four fish species along a polymetallic pollution gradient (Lot River, France). Sci Total Environ 248: $11-25$

Blahová J, Havelková M, Kružíková K, Hilscherová K, Halouzka R, Modrá H, Grabic R, Haliřová J, Jurčiková J, Ocelka T, Haruštiaková D, Svobodová Z 2010: Assessmant of contamination of the Svitava and Svratka rivers in the Czech Republic using selected biochemical markers. Environ Toxicol Chem 29: 541-549

Blahová J, Kružíková K, Tomsejová S, Hilscherová K, Stierand P, Jurčíková J, Svobodová Z 2009: An assessment of PAHs contamination of the Svitava and Svratka rivers, Czech Republic. Toxicol Lett 189: 190

Bowen HJM 1979: Environmental chemistry of the elements. Academic Press, London, 269 p

Burger J, Gaines KF, Boring CS, Stephens WL, Snodgrass J, Dixon C, McMahon M, Shukla S, Shukla T, Gochfeld M 2002: Metal levels in fish from the Savannah River: Potential hazards to fish and other receptors. Environ Res 89: 85-97

Castro-Gonzalez MI, Mendez-Armenta M 2008: Heavy metals: Implications associated to fish consumption. Environ Toxicol Phar 26: 263-271

Cornelis R, Caruso J, Crews H, Heumann K 2005: Handbook of Elemental Speciation II. Species in the environment, food, medicine and occupational health. Wiley, Chichester, $781 \mathrm{p}$

Čelechovská O, Svobodová Z, Randák T 2005: Arsenic content in tissues of fish from the River Elbe. Acta Vet Brno 74: 419-425

Čelechovská O, Harkabusová V, Macharáčková B, Vitoulová E, Lavičková A 2011: Accumulation of arsenic during the growing period of rainbow trout (Oncorhynchus mykiss). Acta Vet Brno 80: 219-225

Čelechovská O, Svobodová Z, Žlábek V, Macharáčková B 2007: Distribution of metals in tissues of the common carp (Cyprinus carpio L.). Acta Vet Brno 76: 93-100

Chevreuil M, Carru A, Chesterikoff A, Boët P, Tales E, Allardi J 1995: Contamination of fish from different areas of the river Seine (France) by organic (PCB and pesticides) and metallic $(\mathrm{Cd}, \mathrm{Cr}, \mathrm{Cu}, \mathrm{Fe}, \mathrm{mn}, \mathrm{Pb}$ and $\mathrm{Zn}$ ) micropollutants. Sci Total Environ 162: $31-42$

Has-Schön E, Bogut I, Strelec I 2006: Heavy metal profile in five fish species included in human diet, domiciled in the end flow of River Neretva (Croatia). Arch Environ Contam Toxicol 50: 545-551

Kovářová J, Blahová J, Havelková M, Kružíková K, Tomsejová S, Jurčíková J, Haruštiaková D, Svobodová Z 2009a: Assessment of POP's contamination of the Svitava and Svratka rivers using selected biochemical markers. Toxicol Lett 189: 193

Kovářová J, Čelechovská O, Kízek R, Adam V, Haruštiaková D, Svobodová Z 2009b: Effect of metals, with special attention of Cd, content of the Svitava and Svratka rivers on levels of thiol compounds in fish liver and their use as biochemical markers. Neuroendocrinol Lett 30: 169-176

Kružíková K, Randák T, Kenšová R, Kroupová H, Leontovyčová D, Svobodová Z 2008:

Mercury and methylmercury concentrations in muscle tissue of fish caught in major rivers of the Czech Republic. Acta Vet Brno 77: 637-643

Kružíková K, Blahová J, Kenšová R, Jurčíková J, Hypr D, Svobodová Z 2009: Mercury and methylmercury content in chub from the Svitava and Svratka rivers at agglomeration Brno. Czech J Food Sci 27: 470-476

Kružíková K, Kenšová R, Blahová J, Svobodová Z 2011: Assessment of mercury contamination of the Svitava and Svratka rivers and muscle of chub (Leuciscus cephalus L.) in urban agglomeration of Brno in the Czech Republic. Acta Vet Brno 80: 227-233

Linde AR, Sánchez-Galán S, Klein D, Gárcia-Vazquéz E, Summer KH 1999: Metallothionein and heavy metals in Brown Trout (Salmo trutta) and European Eel (Anguilla anguilla): Comperative Study. Ecotox Environ Safe 44: $168-173$

Yilmaz F, Özdemir N, Demirak A, Tuna L 2007: Heavy metal levels in two fish species Leuciscus cephalus and Lepomis gibbosus. Food Chem 100: 830-835 